\title{
Contribution to the Study of Paleoproterozoic Materials for the Improvement of Social Housing in the Kedougou Region: Case of Mako Andesitic Meta-Tuffs
}

\author{
Abdou Diouf, Adama Dione, Mahamadane Diene, Matar Ndiaye \\ Institut des Sciences de la Terre, Faculté des Sciences et Techniques, Université Cheikh Anta Diop, Dakar, Senegal \\ Email: abdoudiouf64@hotmail.fr, adama15.dione@ucad.edu.sn,mahamadane@netcourrier.com,matar.ndiaye@ucad.edu.sn
}

How to cite this paper: Diouf, A., Dione, A., Diene, M. and Ndiaye, M. (2020) Contribution to the Study of Paleoproterozoic Materials for the Improvement of Social Housing in the Kedougou Region: Case of Mako Andesitic Meta-Tuffs. Journal of Building Construction and Planning Research, 8, 42-56.

https://doi.org/10.4236/jbcprt.2020.81004

Received: October 2, 2019

Accepted: January 28, 2020

Published: January 31,2020

Copyright $\odot 2020$ by author(s) and Scientific Research Publishing Inc. This work is licensed under the Creative Commons Attribution International License (CC BY 4.0).

http://creativecommons.org/licenses/by/4.0/

\begin{abstract}
The objective of this project is the valorization of Mako andesitic volcanic tuffs for use in social housing in the Kedougou region. To achieve these objectives, a geotechnical characterization of the tuff samples was carried out and the geopolymerization stabilization was adopted for the manufacture of bricks. These bricks stabilized by an alkaline activation offer compressive strengths that exceed the threshold value $(2.9 \mathrm{MPa})$ set by the standard (NF P14-304). The best compressive strengths (12.14 MPa) and flexural tensile strengths $(5.43 \mathrm{MPa})$ are obtained in the series of bricks made with $35 \%$ of the mass of a solution of caustic soda at 12 molars concentration with a curing temperature cooking of $185^{\circ} \mathrm{C}$ and an average absorbance of $13.21 \%$.
\end{abstract}

\section{Keywords}

Mako, Volcanic Tuffs, Geopolymerization, Alkaline Activation

\section{Introduction}

Senegal, a country located on the extreme western part of the African continent, has diversified natural resources. It recorded volcanic activity almost two (2) billion years ago. The region of Kedougou is marked by this phase during which several outcrops of volcanic rocks of different natures were formed. The volcanic formations of Mako and Bafoundou are evidences of this period with the massive presence of volcanic tuffs of several varieties.

On the one hand, Kedougou is home to one of the poorest and most vulnerable populations in the country who are struggling to have decent housing. On 
the other hand, in this eastern part of the country, more precisely in the districts of Mako and Bafoundou, there is a massive presence of gigantic deposits of volcanic tuffs that are outcropping everywhere.

With the notice of this contrast, we decided to bring solutions to this real problem through a study aiming at the valorization of these volcanic tuffs in order to use them as building material in civil engineering.

Located in the eastern part of the country, the Kedougou region does not have a cement factory and the transport of cement from Thies to Kedougou is still very expensive. It is with this in mind that we will try to manufacture bricks offering good resistance and without cement.

\section{Geological Setting}

In Senegal, the Paleoproterozoic outcrops in the Kedougou-Keniebainlier, which together with that of Kayes form the westernmost part of the West African Craton. The Kedougou-Kéniébainlier is unconformably covered by the Neoproterozoic and Paleozoic geological formations of the Mali and Segou-Madina Kouta series (in the South), the Faleme (in the West) and those of the Taoudeni Basin (in East and North) [1] [2].

The Paleoproterozoic formations of the Kedougou-Keniebainlier are classically divided into two large lithostratigraphic units [3]: to the west, the Mako Super-Group with predominantly mafic volcanic formations and to the East, the Diale-Dalema Super-Group that is essentially sedimentary and volcano-sedimentary (Figure 1).

The predominantly mafic volcanic unit of the Mako Super-Group is composed of basalts with varied textures (in pillow lava or massive) surmounted by a calc-alkaline volcanism constituting a volcano-sedimentary complex with andesitic tuffs that can evolve towards rhyolitic tuffs. At the top, lies a sedimentary complex [1] [4].

The sedimentary and volcano-sedimentary formations of the Diale-Dalema Group, to the East of the Mako Group, consist mainly of carbonate rocks, schists, pelites, sandstones, arkoses, greywackes, conglomerates and tuffs. They are intersected by an intermediate volcanism of calco-alkaline nature ([1] [5] [6] her, 1987 [7]) dated around $2081 \mathrm{Ma}$ [8]. The formations of the Foulde Group in the northwest of the Mako Group are essentially detrital [9].

All volcanic, volcano-sedimentary and sedimentary formations are affected by regional metamorphism of green schist facies and are intersected by magmatic suites consisting of calc-alkaline plutonic rocks of various types [1], whose age extends from 2158 [10], to $2050 \mathrm{Ma}$.

The andesitic meta-tuffs formations were first mapped by and they constitute the essential of the volcanism to the East of the meta-basalts and appear either in massive flows or in the form of tuffs generally in volcano-detritic bases. The massive rock has a characteristic color with a thickness of about fifty meters and a microlithic-porphyritic texture and an abundance of plagioclase. These andesitic 


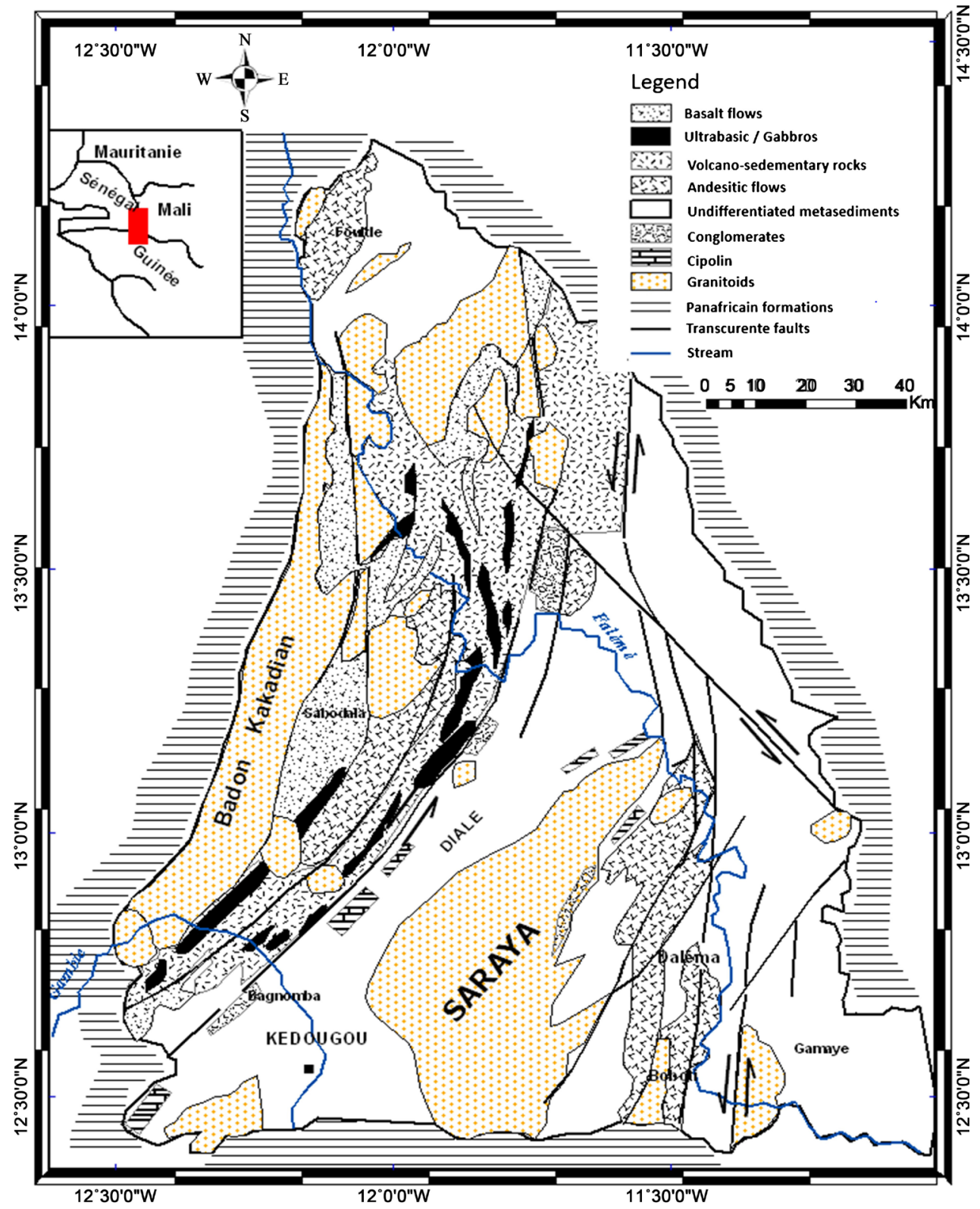

Figure 1. Localisation calco-alkaline of volcanic complex in Mako and Foulde [3].

meta-tuffs can be foliated, mylonitized and even folded.

\section{Background}

Several studies have been carried out on Mako volcanic tuffs [11] [12] [13].

[12] shows that the region of Mako (Eastern Senegal) has a large quantity of volcanic tuffs. These volcanic tuffs are felsic (with nearly $70 \% \mathrm{SiO}_{2}$ ). This high content of silica and aluminum (13\%) gives to the mixture of tuff and binder pozzolanic properties. Bricks of high resistance ( $3 \mathrm{MPa}$ ) from 72 hours of conservation at $80^{\circ} \mathrm{C}$ can be made with the tuffs that are treated with lime (2.5\%). Moreover, Ndiaye (2000) shows that the tuffs have pozzolanic characters and can enter into the composition of CEM II A-P $32.5 \mathrm{R}$ pozzolanic cements type. 
These types can be used to improve the performance of materials. In addition, further studies were conducted by [10] using the geopolymerization process on mine tailings.

Stabilization by geopolymerization with alkaline activation (soda solution) with or without pozzolanic activation has been applied to Sabodala tailings. Thus, the effect of several parameters such as the concentration of the sodium hydroxide solution, the percentage by weight of the solution and the cement and/or the lime, the curing temperature and the type of drying were studied in order to define formulation and preparation protocol that delivers the best results. This enabled to understand the effect of each parameter on improving the performance of the stabilized material but also to be able to predict its resistance as a function of the values of these parameters and the method of preparation.

\section{Methodology and Experimental Study}

The methodology adopted consists first of all in a thorough literature review, to evaluate the state of knowledge on the stabilization of the materials by geopolymerization method, but also to define protocols to follow to lead to satisfactory results. Laboratory studies will also be carried out to characterize the volcanic tuffs of Mako and build a database, which will allow us to draw graphs and interpret the results obtained. An attempt to implement the results obtained will be made, in order to appreciate the impact of the different parameters involved.

Being a friable and very particular material, the Mako andesitic volcanic tuffs have to meet a certain number of criteria to be used as building materials for the manufacture of bricks for walls and paving bricks. Parameters such as compressive strength, bending tensile strength and good resistance to water should be checked after the chosen treatment option has been applied. They must exceed the thresholds set by the standards in force.

\subsection{Making Bricks from Tuffs}

The bricks must be good quality products and at a lower cost. We used the geopolymerization stabilization method to achieve these objectives but also to guarantee the stability of the material. Geopolymerization is the addition of an alkaline solution $(\mathrm{NaOH}$ or $\mathrm{KOH})$ to alumina silicates. These results in an oligomer-linked polymerization process that results in inorganic polymers similar to zeolites that are able to withstand the most adverse weather conditions.

\subsection{Brick Manufacturing Process by Geopolymerization}

The manufacture of bricks made from volcanic tuff of Mako by the geopolymerization method consists in mixing the previously dried material with a solution of soda prepared at a defined concentration. The making of bricks is done using steel mold.

\subsection{Principle and Procedure}

The principle and the procedure of briquette making include the mixing of the different materials and products used, the molding and demolding of the bri- 
quettes, the drying and finally the thermal activation. A first series of tests was done, initially, and allowed to frame some parameters and to set consequently the number of briquettes necessary for the study.

\subsection{Preparation of Volcanic Tuffs}

The volcanic tuffs are dried in an oven at $105^{\circ} \mathrm{C}$ for 24 hours to remove all interstitial water. The formed blocks are then disintegrated in large basins. The cement is already in the state of powder. Each formulation of the mixture is obtained by fixing the percentage by weight of each constituent and consequently its mass. That of the tuffs is always fixed at $1.4 \mathrm{~kg}$, the mass corresponding to the quantity of material necessary to fill a mold with three briquettes. The tuffs and the cement are then poured into the container and homogenized before adding the soda solution. The paste obtained is placed in the mold and is compacted using an iron bar to eliminate voids. The compaction is manual. Refining of the top surface of briquettes finishes their preparations. Table 1 presents the first series of formulations.

\section{Results}

First series of test formulation was made to define where we can obtain high

Table 1. Composition of different formulations.

\begin{tabular}{ccccc}
\hline formulation $\mathbf{N}^{\bullet}$ & Cement (\%) & Tuff (\%) & Water (\%) & Molar concentration \\
\hline F1 & 0 & 100 & 30 & 5 \\
F2 & 3 & 97 & 40 & 5 \\
F3 & 3 & 97 & 35 & 5 \\
F4 & 5 & 95 & 30 & 5 \\
F5 & 7 & 93 & 30 & 5 \\
F6 & 7 & 93 & 35 & 5 \\
F7 & 0 & 100 & 40 & 8 \\
F8 & 3 & 97 & 35 & 8 \\
F9 & 5 & 95 & 35 & 8 \\
F10 & 7 & 93 & 35 & 5 \\
F11 & 0 & 100 & 45 & 5 \\
F12 & 0 & 100 & 35 & 5 \\
F13 & 0 & 100 & 30 & 8 \\
F14 & 0 & 100 & 45 & 8 \\
F15 & 0 & 100 & 35 & 12 \\
F16 & 0 & 100 & 30 & 8 \\
F17 & 0 & 100 & 30 & 5 \\
F18 & 0 & & & 5 \\
F19 & 0 & 55 & 5 \\
\hline & 0 & 95 & 5 \\
\hline
\end{tabular}


strengths with or without addition of cement but also low concentration of soda at relatively low cooking temperatures. For this, the following 05 parameters have been subject to variation:

- The percentage of cement;

- The percentage of tuff;

- The percentage of mixing water;

- The concentration of the soda solution;

- The cooking temperature of the briquettes.

Table 2 and Table 3 show that the values of the compressive strengths vary

Table 2. Results of few formulations of prime tests for 5 molars concentration.

\begin{tabular}{|c|c|c|c|c|c|c|}
\hline $\begin{array}{l}\text { Formulation } \\
\left(\mathrm{n}^{\circ}\right)\end{array}$ & $\begin{array}{c}\text { Cement } \\
(\%)\end{array}$ & $\begin{array}{l}\text { Tuff } \\
(\%)\end{array}$ & $\begin{array}{c}\text { Water } \\
(\%)\end{array}$ & $\begin{array}{l}\text { Concentration } \\
(\mathrm{m})\end{array}$ & $\begin{array}{c}\text { Temperature. } \\
\left({ }^{\circ} \mathrm{C}\right)\end{array}$ & $\begin{array}{l}\text { Rc 28 } \\
(\mathrm{MPa})\end{array}$ \\
\hline 1 & 0 & 100 & 30 & 5 & 40 & 2.117 \\
\hline 1 & 0 & 100 & 30 & 5 & 60 & 2.29 \\
\hline 1 & 0 & 100 & 30 & 5 & 150 & 2.98 \\
\hline 2 & 3 & 97 & 40 & 5 & 40 & 2.591 \\
\hline 2 & 3 & 97 & 40 & 5 & 60 & 2.667 \\
\hline 2 & 3 & 97 & 40 & 5 & 150 & 6.997 \\
\hline 3 & 3 & 97 & 35 & 5 & 40 & 2.42 \\
\hline 3 & 3 & 97 & 35 & 5 & 60 & 2.63 \\
\hline 3 & 3 & 97 & 35 & 5 & 150 & 6.73 \\
\hline 4 & 5 & 95 & 30 & 5 & 40 & 3.046 \\
\hline 4 & 5 & 95 & 30 & 5 & 60 & 3.871 \\
\hline 4 & 5 & 95 & 30 & 5 & 150 & 4.308 \\
\hline 5 & 7 & 93 & 30 & 5 & 40 & 2.716 \\
\hline 5 & 7 & 93 & 30 & 5 & 60 & 4.153 \\
\hline 5 & 7 & 93 & 30 & 5 & 150 & 4.487 \\
\hline 6 & 7 & 93 & 35 & 5 & 40 & 2.855 \\
\hline 6 & 7 & 93 & 35 & 5 & 60 & 3.529 \\
\hline 6 & 7 & 93 & 35 & 5 & 150 & 14.172 \\
\hline 7 & 0 & 100 & 40 & 8 & 40 & 2.179 \\
\hline 7 & 0 & 100 & 40 & 8 & 60 & 2.997 \\
\hline 7 & 0 & 100 & 40 & 8 & 150 & 17.735 \\
\hline 8 & 3 & 97 & 35 & 8 & 40 & 1.472 \\
\hline 8 & 3 & 97 & 35 & 8 & 60 & 1.923 \\
\hline 8 & 3 & 97 & 35 & 8 & 150 & 7.758 \\
\hline 9 & 5 & 95 & 35 & 8 & 40 & 2.109 \\
\hline 9 & 5 & 95 & 35 & 8 & 60 & 2.845 \\
\hline 9 & 5 & 95 & 35 & 8 & 150 & 6.266 \\
\hline 10 & 7 & 93 & 35 & 8 & 40 & 3.472 \\
\hline 10 & 7 & 93 & 35 & 8 & 60 & 4.923 \\
\hline 10 & 7 & 93 & 35 & 8 & 150 & 8.758 \\
\hline
\end{tabular}


between 1.472 and $17.735 \mathrm{MPa}$. The minimum value (1.472 $\mathrm{MPa}$ ) of resistance is obtained with the category of bricks cured at $40^{\circ} \mathrm{C}$ and the maximum value $(17.735 \mathrm{MPa})$ with the category cured at $150^{\circ} \mathrm{C}$. This shows that the temperature parameter is very decisive for the desired results. The evolution of the compressive strength as a function of the curing temperature is illustrated in Figure 2.

Figure 2 shows the evolution of the compressive strength as a function of the curing temperature. It shows that the compressive strength of bricks is strongly influenced by each of the parameters, namely the percentage of cement, the percentage of the mixing water of the soda solution and its concentration. The curve indicates that the curing temperature increases with compressive strength. The best resistance is provided by Formulation $6(14.17 \mathrm{MPa})$ for which the composition of the briquettes is $7 \%$ cement, $35 \%$ water, 5 molars concentration of sodium hydroxide and curing temperature of $150^{\circ} \mathrm{C}$.

The same observation is made for the 8 molars concentration formulations (Figure 3).

The higher the curing temperature is, the higher the compressive strengths. But, the best resistance is provided by the Formulation $7(17.73 \mathrm{MPa})$ with bricks made without cement and with $100 \%$ tuff, $40 \%$ water, 8 molars soda concentration

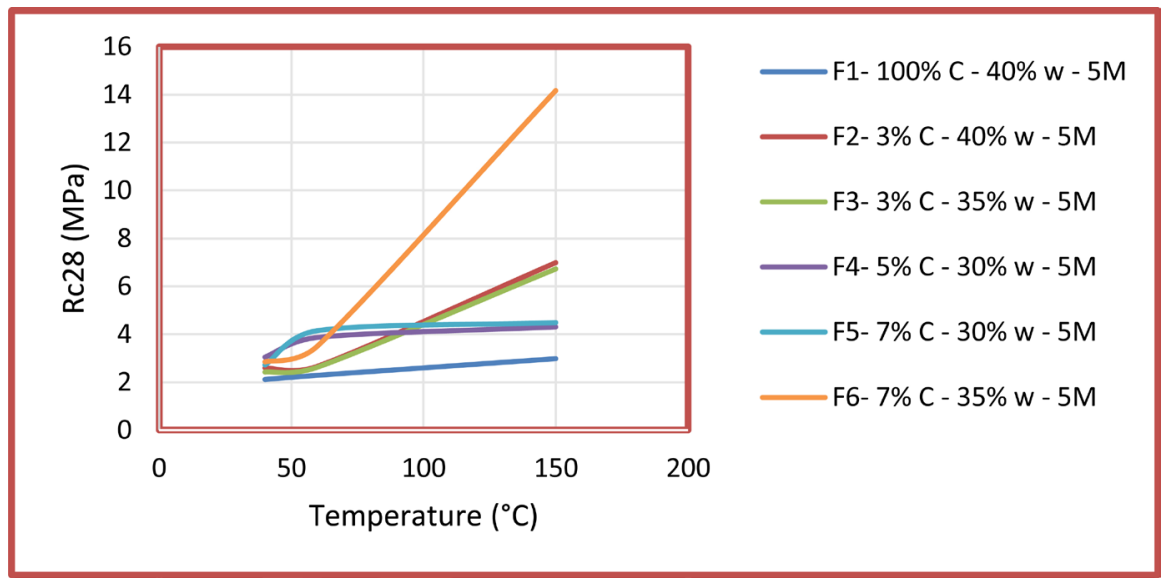

Figure 2. Evolution of compression resistance as a function of temperature for formulations at 5 molars concentration.

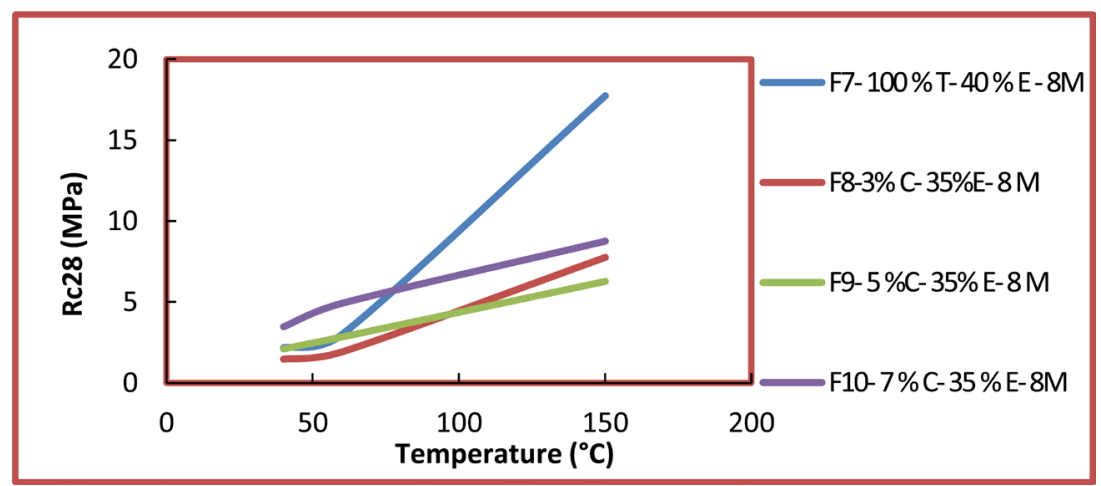

Figure 3. Evolution of compression resistance as a function of temperature for formulations at 8 molars concentration. 
and $150^{\circ} \mathrm{C}$ curing temperature. This remark gave us the idea of making formulations without adding cement. So for all the formulations that did follow consist of briquettes with $100 \%$ Mako volcanic tuff.

\subsection{Resistance as a Function of the Concentrations of the Soda Solution}

The briquettes were made with $100 \%$ tuff, $30 \%, 35 \%$ and $45 \%$ sodium hydroxide solution. Relatively low curing temperature of $50^{\circ} \mathrm{C}$ for $24 \mathrm{~h}$, tests run on the $28^{\text {th }}$ day and drying under cover have been respected. Figure 4 shows the influence of the concentration on the compressive strength in the manufacturing conditions mentioned above.

The results show that at $50^{\circ} \mathrm{C}$, the best resistances are noted with a concentration of 8 molars for the sodium hydroxide solution with a percentage of mixing water of $35 \%$ (Figure 5).

For the curing temperature of $80^{\circ} \mathrm{C}$, the results also show that the best performances in terms of strengths are noted with a concentration of 8 molars for the sodium hydroxide solution with a percentage of mixing water of $35 \%$, the same effect being obtained at $50^{\circ} \mathrm{C}$ curing temperature (Figure 6).

A clear difference is observed between the results of briquettes cured at $185^{\circ} \mathrm{C}$

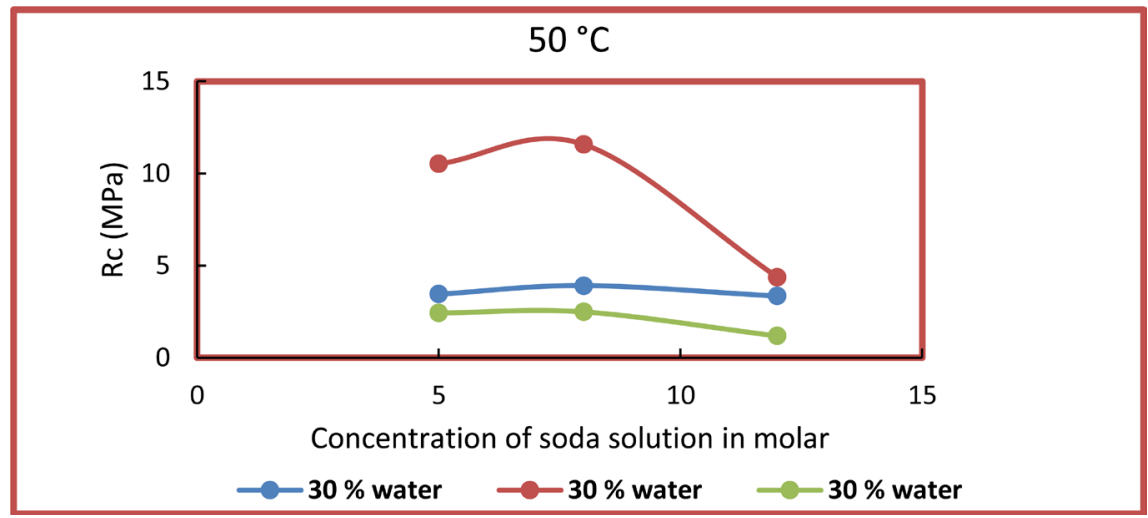

Figure 4. Variation of resistance as function of concentration of soda at $50^{\circ} \mathrm{C}$.

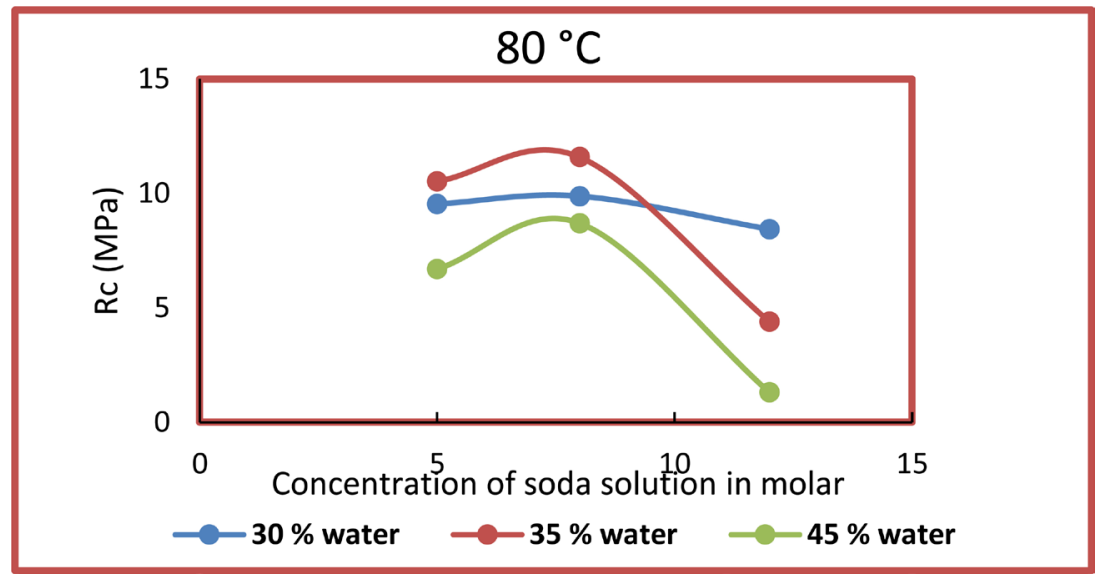

Figure 5. Variation of resistance as function of concentration of soda at $80^{\circ} \mathrm{C}$. 
and those at $50^{\circ} \mathrm{C}$ and $80^{\circ} \mathrm{C}$. Here, the results show an increase of the resistances with the increase of the concentration of the solution of soda $(5,8$ and 12 molars). At $185^{\circ} \mathrm{C}$, the reactions begin. In fact, the $\mathrm{pH}$ becomes more and more alkaline with the increase of the concentration of the sodium hydroxide solution thus creating the conditions of more abundant rupture of the bonds of the crystalline structure and thus leading to the formation of new bonds which give rise to the amorphous gel. In addition, an increasingly concentrated solution provides a larger amount of $\mathrm{Na}+$ cations that enter into the constitution of the gel.

\subsection{Resistances as a Function of the Percentage by Mass of Soda Solution}

The percentages in mass of the soda solution used are $30 \%, 35 \%$ and $45 \%$ respectively for the concentrations. Sodium concentrations for each series are 5, 8 and 12 molars. We have three sets of bricks at $50^{\circ} \mathrm{C}, 80^{\circ} \mathrm{C}$ and $185^{\circ} \mathrm{C}$, respectively. The results obtained are shown in Figure 7. The curves show the evolution of the compressive strength as a function of the percentages by weight of the sodium hydroxide solution.

The analysis of the curves shows that a variation of the proportion of the soda solution gives the optimum at $35 \%$ for the concentrations of 5 and 8 molars. Too

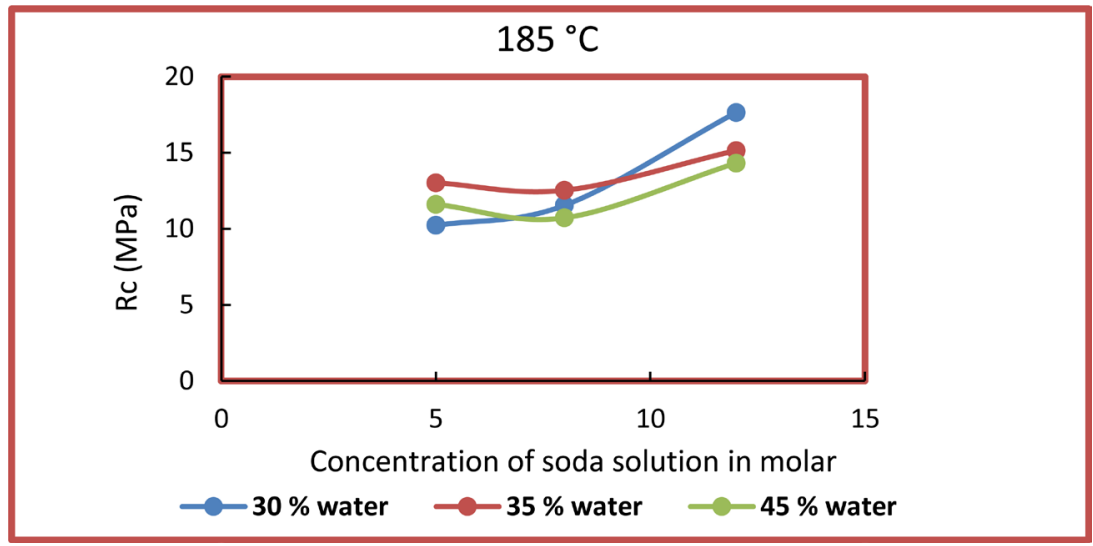

Figure 6. Variation of resistance as function of concentration of soda at $185^{\circ} \mathrm{C}$.

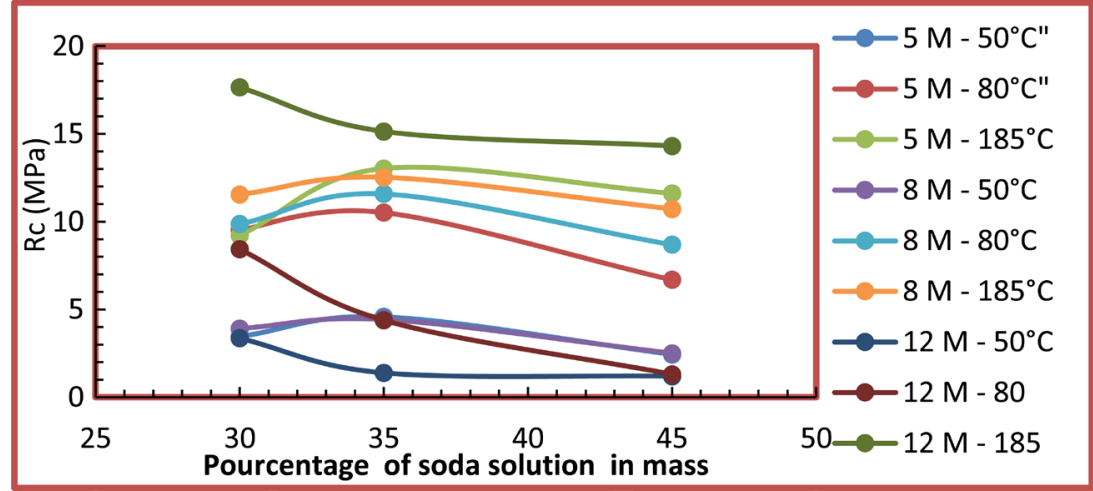

Figure 7. Variation of the compressive strength as a function of the percentages by weight of the sodium hydroxide solution. 
little amount of solution does not allow sufficient contact between it and the surfaces of the particles of the tuffs. These results about limitations of the geopolymerization with small quantities of neo-formed gel explain the decrease of the resistances to the left of the optimum. On the other hand, when the solution is too abundant, the liquid/solid ratio which is too high leads to an increase in the porosity and a decrease in the compactness which causes the reduction of the resistances to the right of the optimum. But unlike the concentration of 12 molars, the resistance decreases with the increase of the proportion of the soda solution.

\subsection{Resistances as a Function of the Curing Temperatures}

The evolution of the compressive strength as a function of the curing temperature has been studied. The results obtained are translated into curves. The different curves are identified with respect to the percentage of the sodium hydroxide solution that served as the mixing water. The results are shown in Figure 8 .

Figure 8 shows the evolution of the compressive strength of the bricks as a function of the curing temperature. The shape of the curves for the 5 molars and 8 molars concentrations indicates identical patterns. Note that the resistance increases with the temperature up to $12 \mathrm{MPa}$ at which the resistances remain constant. Unlike for a concentration of 12 molars, curves show a progressive increase in resistance when the temperature increases.
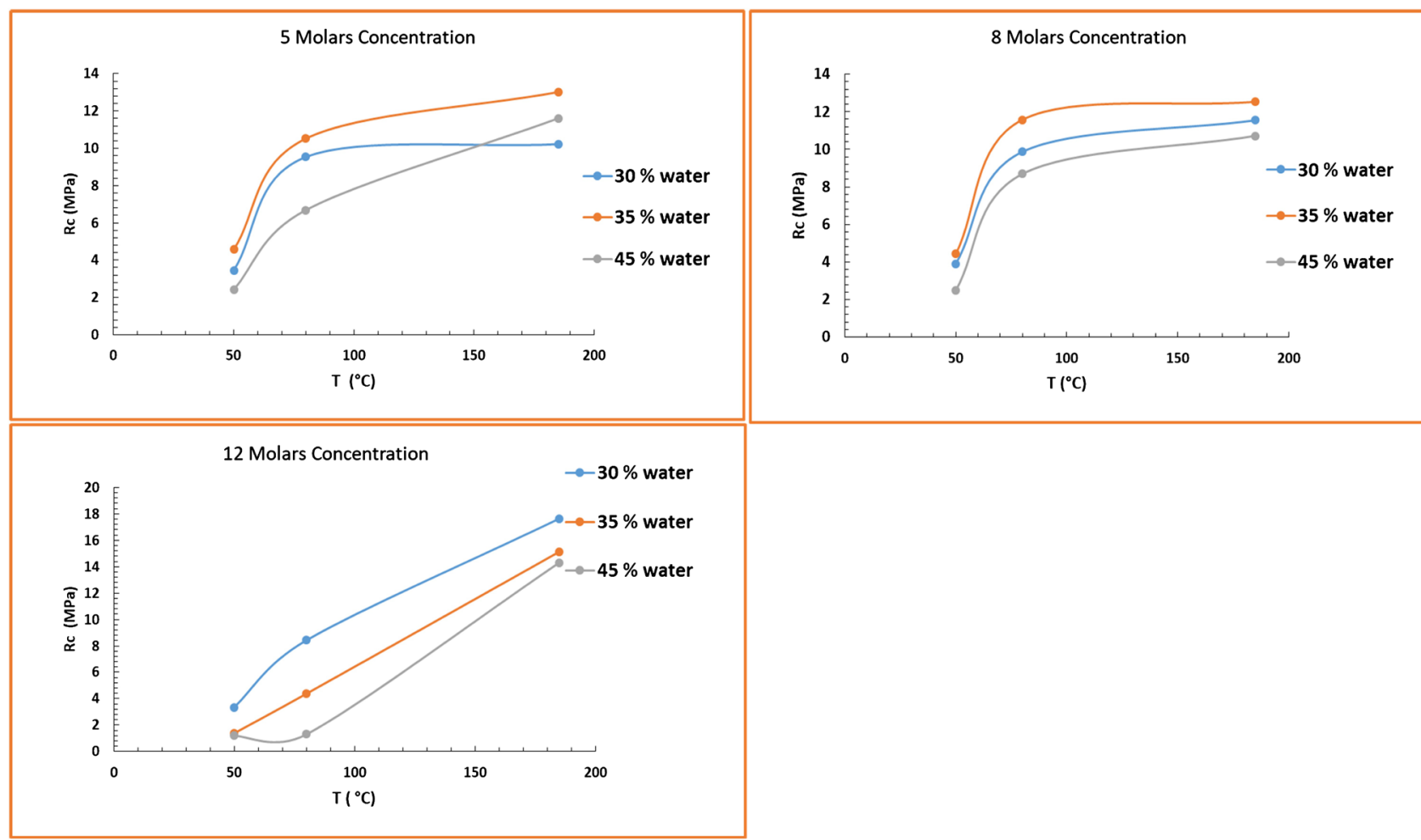

Figure 8. Variation of the compressive strength of the bricks as a function of the curing temperature for the 5 molars, 8 molars and 12 molars concentrations. 


\subsection{Flexural Tensile Strength of Bricks}

The flexural tensile strengths measured vary according to the various parameters involved in the composition of the briquettes. We ranked the results for each set of bricks according to the concentration. The results obtained after testing the briquettes are shown in Tables 3-5.

The results of the tensile strength by flexion test for a concentration of 5 molars show that the bricks which are more resistant to flexion are located in the series of bricks treated at $185^{\circ} \mathrm{C}$ where the maximum tensile strength reaches $1.865 \mathrm{MPa}$. The values obtained as a function of the percentage of the water indicate an optimum at $35 \%$.

For bricks made at 8 molars concentration, we noticed the same variations. The results show that the bricks which are more resistant to flexion are located in the $185^{\circ} \mathrm{C}$ series of bricks where the maximum tensile strength is $1.442 \mathrm{MPa}$. The values obtained as a function of the percentage of the sodium hydroxide solution indicate a $35 \%$ optimum. Resistances are nil at $50^{\circ} \mathrm{C}$ curing temperature.

Table 3. Result of traction resistance for 5 molars concentration.

\begin{tabular}{ccccccc}
\hline $\begin{array}{c}\% \\
\text { Cement }\end{array}$ & $\begin{array}{c}\% \\
\text { Tuff }\end{array}$ & $\begin{array}{c}\% \\
\text { Water }\end{array}$ & $\begin{array}{c}\text { Concentration } \\
(\text { Molar })\end{array}$ & $\begin{array}{c}\text { Temperature } \\
\left({ }^{\circ} \mathrm{C}\right)\end{array}$ & $\begin{array}{c}\text { Load } \\
(\mathrm{N})\end{array}$ & $\begin{array}{c}\mathbf{R}_{\mathrm{t}} \\
(\mathrm{MPa})\end{array}$ \\
\hline 0 & 100 & 45 & 5 & 50 & 0.801 & 0.342 \\
0 & 100 & 35 & 5 & 50 & 1.288 & 0.55 \\
0 & 100 & 30 & 5 & 50 & 1.224 & 0.522 \\
0 & 100 & 30 & 5 & 80 & 4.37 & 1.082 \\
0 & 100 & 35 & 5 & 80 & 4.37 & 1.423 \\
0 & 100 & 45 & 5 & 80 & 1.938 & 1.21 \\
0 & 100 & 30 & 5 & 185 & 2.535 & 1.865 \\
0 & 100 & 35 & 5 & 185 & 3.336 & 1.865 \\
0 & 100 & 45 & 5 & 185 & 1.937 & 0.827 \\
\hline
\end{tabular}

Table 4. Result of traction resistance for 8 molars concentration.

\begin{tabular}{ccccccc}
\hline $\begin{array}{c}\% \\
\text { Cement }\end{array}$ & $\begin{array}{c}\% \\
\text { Tuff }\end{array}$ & $\begin{array}{c}\% \\
\text { Water }\end{array}$ & $\begin{array}{c}\text { Concentration } \\
(\mathbf{M})\end{array}$ & $\begin{array}{c}\text { Temperature } \\
\left({ }^{\circ} \mathrm{C}\right)\end{array}$ & $\begin{array}{c}\text { Load } \\
(\mathrm{kN})\end{array}$ & $\begin{array}{c}\text { Rt } \\
(\mathrm{MPa})\end{array}$ \\
\hline 0 & 100 & 45 & 8 & 50 & 0 & 0 \\
0 & 100 & 35 & 8 & 50 & 0 & 0 \\
0 & 100 & 30 & 8 & 50 & 0 & 0 \\
0 & 100 & 30 & 8 & 80 & 1.996 & 0.852 \\
0 & 100 & 35 & 8 & 80 & 4.137 & 1.765 \\
0 & 100 & 45 & 8 & 80 & 2.535 & 1.082 \\
0 & 100 & 30 & 8 & 185 & 3.176 & 1.355 \\
0 & 100 & 35 & 8 & 185 & 3.38 & 1.442 \\
0 & 100 & 45 & 8 & 185 & 2.054 & 0.876 \\
\hline
\end{tabular}


The bricks made at the concentration of 12 molars and cured at the temperature of $185^{\circ} \mathrm{C}$ have values of tensile strength by maximum traction of $2.318 \mathrm{MPa}$. We noticed the same variations as the previous table of results. Bricks that are more resistant to traction are located in the $185^{\circ} \mathrm{C}$ series of bricks. The values obtained as a function of the percentage of the sodium hydroxide solution indicate a $35 \%$ optimum. Resistances are nil at $50^{\circ} \mathrm{C}$ curing temperature.

\subsection{Results of Measurement of Water Absorption Rate of Briquettes}

Measurements of the water absorption rate were made after 6 days after immersing the bricks in basins filled with water (Figures 9-11).

After the flexural tensile test, the brick is split into two parts. The first half of the brick is used to measure the compressive strength and the second half to determine the water absorption rate. The results obtained are recorded in Figure 9.

The results show that the highest absorbance rates are in the series of bricks made at $45 \%$ by weight of the sodium hydroxide solution. Bricks made at $35 \%$ are the ones with the best results. So, we can remember that there are fewer voids at this level of mixing where the percentage of the solution used is $35 \%$.

Table 5. Result of traction resistance for 12 molars concentration.

\begin{tabular}{ccccccc}
\hline $\begin{array}{c}\% \\
\text { Cement }\end{array}$ & $\begin{array}{c}\% \\
\text { Tuff }\end{array}$ & $\begin{array}{c}\% \\
\text { Water }\end{array}$ & $\begin{array}{c}\text { Concentration } \\
(\mathbf{M})\end{array}$ & $\begin{array}{c}\text { Temperature } \\
\left({ }^{\circ} \mathrm{C}\right)\end{array}$ & $\begin{array}{c}\text { Load } \\
(\mathrm{kN})\end{array}$ & $\begin{array}{c}\mathrm{Rt} \\
(\mathrm{MPa})\end{array}$ \\
\hline 0 & 100 & 45 & 12 & 50 & 0 & 0 \\
0 & 100 & 35 & 12 & 50 & 0 & 0 \\
0 & 100 & 30 & 12 & 50 & 0 & 0 \\
0 & 100 & 30 & 12 & 80 & 1.904 & 0.814 \\
0 & 100 & 35 & 12 & 80 & 2.287 & 0.976 \\
0 & 100 & 45 & 12 & 80 & 1.883 & 0.804 \\
0 & 100 & 45 & 12 & 185 & 5.392 & 2.300 \\
0 & 100 & 35 & 12 & 185 & 5.434 & 2.318 \\
0 & 100 & 30 & 12 & 185 & 3.366 & 2.289
\end{tabular}

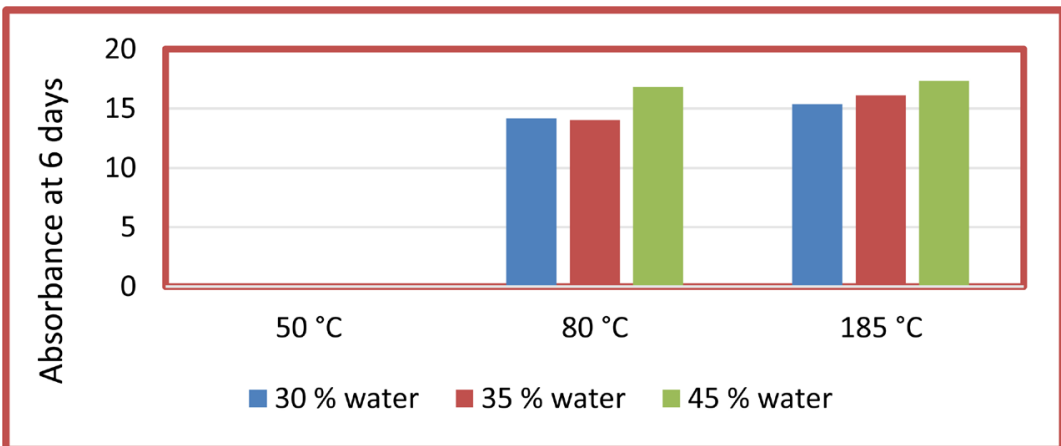

Figure 9. Results for absorbency ratio for brick of 5 molars concentration. 


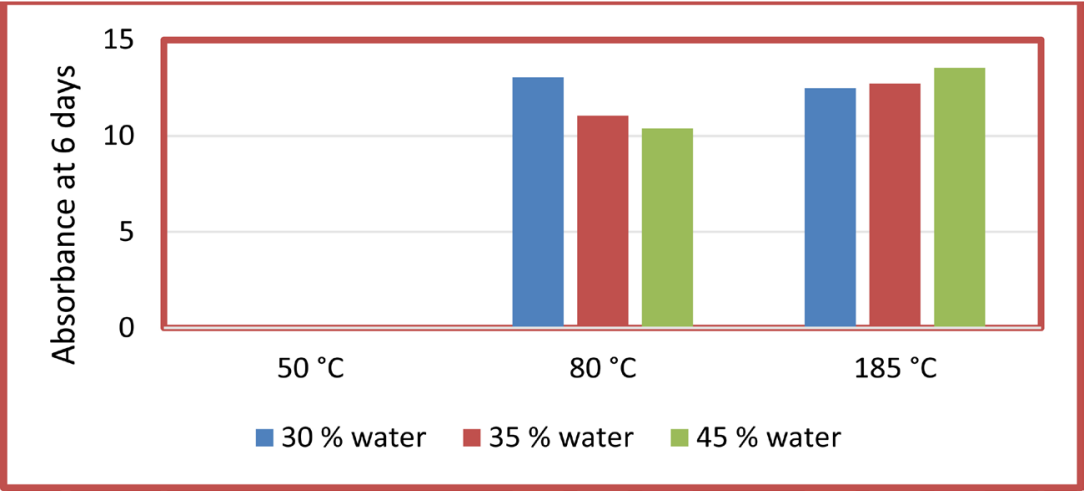

Figure 10. Results for absorbency ratio for brick of 8 molars concentration.

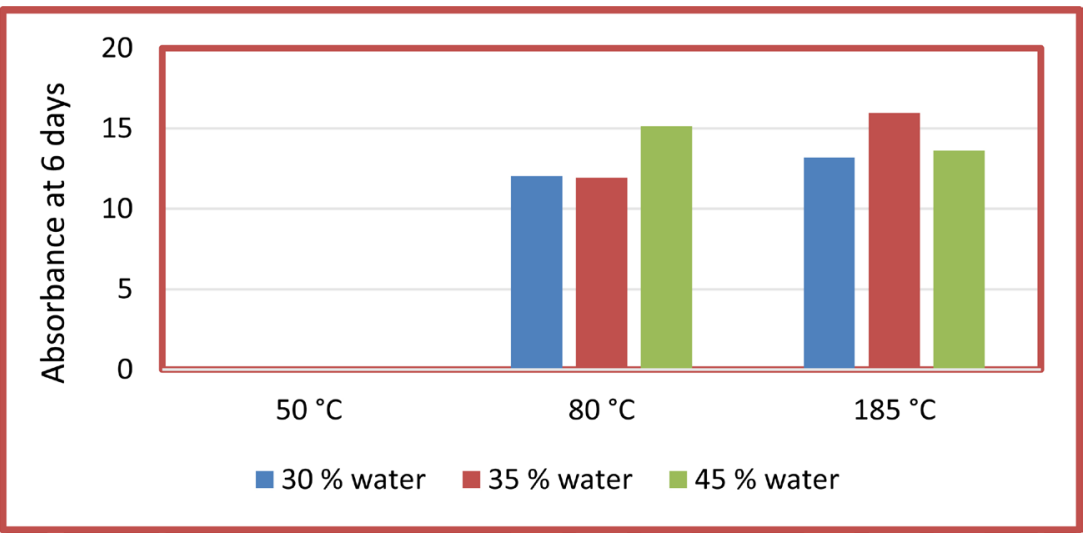

Figure 11. Results for absorbency ratio for brick of 12 molars concentration.

Same remark as for the bricks made with a concentration of 5 molars was done. The results show that the highest absorbance rates are in the series of bricks made at $45 \%$ by weight of the sodium hydroxide solution. Bricks made at $35 \%$ are the ones with the best results.

For these bricks with a concentration of 12 molars, we noticed an inconsistency in the absorbance levels found. With a cooking temperature of $185^{\circ} \mathrm{C}$, the best absorbance rates are $45 \%$ by weight of the sodium hydroxide solution.

\section{Conclusion}

In general, we can remember that the curing temperature increases with the compressive strength. The best resistances are noted at 8 molars concentration of the sodium hydroxide solution with a percentage of mixing water of $35 \%$. The analysis of the curves shows that a variation of the proportion of the soda solution gives the optimum at $35 \%$ for the concentrations of 5 and 8 molars. But unlike the concentration of 12 molars, the resistance decreases with the increase of the proportion of the soda solution. These results in a limitation of the geopolymerization with small quantities of neo-formed gel explain the decrease of the resistances to the left of the optimum. On the other hand, when the solution is too abundant, the liquid/solid ratio which is too high leads to an increase in the porosity and a decrease in the compactness which causes the reduction of the re- 
sistances to the right of the optimum. Bricks that are more resistant to bending are located in the $185^{\circ} \mathrm{C}$ series of bricks. Bricks manufactured at $35 \%$ are the ones with the best results in terms of absorbance.

\section{Conflicts of Interest}

The authors declare no conflicts of interest regarding the publication of this paper.

\section{References}

[1] Bassot, J.P. (1966) Etudes géologiques du Sénégal oriental et de ses confins guinéo-maliens. $\mathrm{N}^{\circ}$ 40, éd. B.R.G.M., $321 \mathrm{p}$.

[2] Bessoles, B. (1977) Géologie de l'Afrique: le Craton Ouest Africain. Mémoire. Bureau de Recherche de la Géologie et Minière, 88, 402 p.

[3] Ledru, M.P. (1991) Etude de la pluie pollinique actuelle des forêts du Brésil central: climat, végétation, application à l'étude de l'évolution paléoclimatique des 30.000 dernières années. Muséum National d'Histoire Naturelle, Paris, 267 p. Thèse en. Sciences. Naturelles.: Géologie, Muséum National d'Histoire Naturelle.

[4] Ngom, P.M. (1995) Caractérisation de la croûte birimienne dans les parties centrale et méridionale du Supergroupe de Mako. Implications géodynamiques et pétrogénétiques. Thèse d'Etat UCAD, $240 \mathrm{p}$.

[5] N'Diaye, P.M. (1994) Evolution au Protérozoïque inférieur de la région Est-Saraya (craton de l'Afrique de l'Ouest, Sénégal-Mali). Tourmalinisations, altérations hydrothermales et minéralisations associées. Thèse d'Etat UCAD, $372 \mathrm{p}$.

[6] Boher, M. (1987) Pétrographie et géochimie des formations de la Daléma (Sénégal Oriental). Les formations métamorphiques du sillon de Yalogo (Burkina Faso). Premières datations $\mathrm{Sm}-\mathrm{Nd}$ et $\mathrm{Rb}$-Sr. Diplôme d'Etudes Approfondies de l'Université Nancy I, $44 \mathrm{p}$.

[7] Boher, M., Abouchami, W., Michard, A., Albarède, F. and Arndt, N.T. (1992) Crustal Growth in West Africa at 2.1 Ga. Journal of Geophysical Research, 97, 345-369. https://doi.org/10.1029/91jb01640

[8] Calvez, J.Y., Feybesse, J.L., Ledru, P. and Milesi, J.P. (1990) Géochronologie du Protérozoïque inférieur du craton ouest africain (méthode d'évaporation directe de zircons isolés). 13eme réunion des Sciences de la Terre, Grenoble, France, $26 \mathrm{p}$.

[9] Dioh, E. (1995) Caractérisation, signification et origine des formations birimiennes encaissantes de granite de Dioumbalou (Partie septentrionale de la boutonnière de Kédougou-Sénégal Oriental). Thèse d'Etat UCAD, 427 p.

[10] Dia, A., Van Schmus, W.R. and Kroner, A. (1997) Isotopic Constraints on the Age And Formation of a Paleoproterozoic Colcanic Arc Complex in the Kedougou Inlier, Eastern Senegal, West Africa. Journal of African Earth Sciences, 24, 197-213. https://doi.org/10.1016/s0899-5362(97)00038-9

[11] Boiro, A. (2006) Caractérisation et valorisation de matériaux argileux du Sénégal oriental en briqueterie: Cas des tufs volcaniques du secteur de Mako. Thèse de troisième cycle de géosciences; option environnement sédimentaire, UCAD, 97.

[12] Diop, M.B., Boiro, A., Jauberthie, R. and Bouguerra, A. (2008) Traitement à la chaux des tufs volcaniques du Sénégal oriental Activation de la réaction pouzzolanique par du phosphogypse. Déchets sciences et techniques, No. 49, 20-24. https://doi.org/10.4267/dechets-sciences-techniques.1427 
A. Diouf et al.

[13] N'Diaye, M., et al. (2003) Pouzolanic Activity of Acid and Intermediary Volcanic Tuffs of Mako Areas (Senegal). International Symposium on Industrial Minerals and Building Stones, 15-18 September 2003, 15-18. 